\title{
UNIVERSITIES OF THE THIRD AGE AS A CHANCE FOR SENIORS TO INTEGRATE INTO THE MULTICULTURAL SOCIETY
}

\author{
aŽANETA BALÁŽOVÁ \\ Technical University in Zvolen, T.G.Masaryka 24, 96001 \\ Zvolen, Slovak Republic \\ email: a zanetabalazova@tuzvo.sk
}

Grant: 010TU Z-4/2017 (Cultural and Educational Grant Agency of the Ministry of Education, Science, Research and Sport of the Slovak Republic) Name of the Grant: Developing the Reading Competency and Teaching Technical Foreign Languages at Technical Universities

Abstract: International cooperation, visiting new countries, meeting new people from all over the world are typical features of these days. The Universities of the Third Age as institutions focused on senior education and their opportunities to help people of older age familiarize with new cultures, it means to integrate into the multicultural older age familiarize with new cultures, it means to integrate into the multicultural society are presented in the paper. The European Union, especially the Erasmus+ program offers chances to students of all ages as well as seniors to enhance the knowledge and skills abroad, to make friends and to improve communication skills in
English language.

Keywords: senior, University of the Third Age, ERASMUS+ program, culture, international project

\section{Introduction}

At the present time, everything that people do, speak or think about, i.e. extensive set of phenomena including knowledge, language, ethics, law, art, culture, education and action, everything used by people to find direction in the world and at the same time, to create the world can be understood as culture. Human perception and understanding is mediated by culture or various cultures. What is perceived as beautiful, tasty, true is determined by members of other cultures differently, within the context of the culture they grew up. A socio-cultural system consists of dominant culture, subcultures (set of specific features of a culture typical for social groups in specific society), and contra cultures (holding values opposite the dominant culture) as well as art, folk and mass culture (Petrusek, 2002. p. 36). Coexistence of different cultures able to develop and enrich mutually is a key feature of full-blown Europe, thus the multicultural principles in education must be followed. Development of the ability to tolerate other cultures, or respect the existence of other cultures means the ability to look at the world through the eyes of other cultures or to respect heterogeneity (Zelenická, 2006, p. 267). Process of globalization and entry to the European Union provide the opportunity for meeting members of various cultures. Respecting cultural and language heterogeneity is an essential principle of running the EU successfully. It is closely connected with foreign language acquisition - trend leading to the tolerance of otherness.

\section{Senior as a target group of education}

An increase in the number of older people in population is one of the impacts of demographic ageing. The term of senior is used to determine this group of people by Rychtař́ková (2002, p. 45). This term is frequently used not only in demography but also in other scientific branches (e.g. is sociology, education or economics) to define a person at older age. There are various definitions of a senior in literature. According to Jarošová (2006, p. 21), senior is a person with physical, mental and social changes due to the process of ageing. Čornaničová (2007, p. 52) prefers the opinion that the meaning of a term of a senior is neutral. She also mentions that this term covers and replaces definitions in other branches to define an older person. In other scientific branches, there are still preferred terms such as a geront in gerontology or senescent in psychology (Balogová, 2009). However, both terms used in everyday situations can evoke a person who is old, ill or dependent. In this case, it can be understood improperly or in wrong way. The term retiree or pensioner is associated with social status and with receiving an old age pension.

Boundary line to determine this group of people is not set clearly. People over the age of 65 are considered seniors - older people by the United Nations. In the 1960s, experts of the World Health Organisation made a suggestion to divide middle and old age into following categories:

- $\quad$ middle age 45 - 59 years,

- $\quad$ early old age or young-old age 60-74 years (presenium)

- $\quad$ old - oldest old age, senior age 75-89 years (senium),

- $\quad$ longevity 90 years and more.

Čornaničová (in Balogová, 2009) prefers to use the term of seniors in the case of people 60+ and also the term senium for the stage of life connected with the mentioned age. At the same time, the heterogeneity of the group of older people is highlighted and older people are divided into the categories:

- $\quad$ older person - at the age of 60 to 74, they are considered younger seniors,

- $\quad$ old person - at the age of 75 - 89, they are considered older seniors,

- long-lived person - at the age of 90 and more, they are considered very old seniors.

Economic activity must be taken into consideration when the boundary line is determined. Until recently, the post-productive age of men and women was not the same - in Slovakia, it was 60 or 55 and more. This limitation is the most often used boundary limit of seniority (Vohráliková, Rabušic, 2004). Differences in terminology in society and various laws results also from the different purposes. Therefore, the approach to various issues focused on older people is not uniform. On the other hand, diversity in the social relations of older people, their roles and statuses is pointed out this way. They cannot be perceived as a homogenous group primarily determined by the age. The term senior started to be used in education spontaneously as a term with neutral meaning. Ageing and an old age are important stages of an individual and they are a natural part of life.

\section{System of senior education}

The activity "to want, know and can" direct the personality to self-development is considered an important phenomenon in today's society. According to Barták (2007, p. 16), to want - it can be understood as personal willingness, energizing presented by development of human potential aimed at person's individual as well as team goals. To know - it means the knowledge, what to do, why to do, abilities and skills how to do it as well as experience. To can - it is a category relating to subject as well as object. It depends not only on the subject - persons themselves but especially on the environment where persons can/cannot use their ambitions, needs, interests and the potential.

Adult education is a lifelong process allowing people to keep up with changes in economy, culture and social life. The art of learning is considered a set of skills enhanced by people through their lives (Vacinová, 2013, p. 106). The Universities of the Third Age present the environment where seniors are able to meet their needs, interests and develop their human potential not only through education as their main activity but also through international activities allowing the seniors - older people to integrate into multicultural Europe. Education is not connected with future job but with personal development in the society of other people (Beneš, 2009, p. 26).

Variety of senior formal and informal education provided in the Slovak Republic is quite wide. The focus and the level of formality of individual institutions differ from each other a bit. Universities and Academies of the Third Age are the most popular institutions among seniors. However, other educational activities and programmes offered to seniors not only by these institutions must be mentioned as well. 


\subsection{Universities of the Third Age}

Sources of knowledge acquisition of a person through the life are various. Number of information acquired indirectly is growing constantly. They are assorted and selected according to the value ladder of each person. The form of education is evaluated in the same way. The more they meet the interests, personal needs, the more positively they are perceived. Successful adult education must respect the uniqueness of every individual and follow their strengths (Barták, 2008, p.17)

The Universities of the Third Age (hereafter U3A) are the most popular educational opportunity for seniors. At the same time, the way of senior education provided by them can be considered the most difficult. The First U3A was founded by Pierre Vellas in French town of Toulouse in the year 1973. In the system of lifelong education, the Universities of the Third Age are focused on old population. From their early beginning, they were aimed at the education relating with the hobbies and free time activities of older generation. They are accredited; it means they are official institutions providing education at the highest possible level. Various study branches are designated for the senior population. Completed secondary education with final exam passed and the age of $45+$ are the only conditions to participate in the education at the U3A.

In the 1970s, the term of the U3A presented a new idea in the social policy focused on seniors. Thus, the requirements of the third generation to enable them to stay in contact with education and with other members of society was met. This term is also used to determine other forms of senior education carried out at the universities (institutions providing higher education) or in close cooperation with them. In the past, as well as nowadays, the term of the University of the Third Age is superior to other terms associated with educational activities specified for seniors (Čornaničová, 2007, p. 85).

The focus and the approach of the Universities of the Third Age in the countries all around the world differ. Swindell (2006, p. 430) defines two basic models of the U3A - French and English. University of the Third Age as a part of the university or other institution providing higher education, the use of university premises, as well as services are the conditions of the French model. Content and the form of courses is different but in general, education is provided in a form of lectures, excursions, workshops corresponding with the specialisation of the university. Humanities and art are preferred. Differences can be seen also in a system of financing of the U3A. Some of them are funded by the finances of the university, in some cases the funds consist of combination of fees, presents or direct donations. In Great Britain, French model of the U3A was transformed and new English model was founded. Specialists in various scientific branches go into retirement and subsequently they can stay active and become not only students but also lecturers at the U3A. English model is successfully run not only in Great Britain but also in Australia or New Zealand. The lowest tuition fees charged, lectures held in public or private spaces, libraries or schools, flexible timetables are the biggest advantages of the English model. The choice of courses is wide from scientific lectures to workshops of handicraft or physical activity. Each University of the Third Age is independent managed by elected management consisting of their members. At the present time, all Universities of the Third Age around the world identify with one of the mentioned models or they create so-called hybrid form based on both English and French model.

In respect to preparing the educational programmes for seniors, two concepts are used world-wide. Segregation concept of senior education is the first one. It is based on the separation of full time students and senior students, there is no connection between the two groups of students. This concept is focused on education associated with hobbies without any chances to get better qualification. Integration concept is the second one. Full-time students are integrated with senior students. Connection of generations and exchange of experience is considered the biggest advantage of the concept (Veteška, 2009, p. 167).
Following the mentioned facts, it is clear that the Universities of the Third Age vary in their structure. Cornaničová (2007, p. 85) describes the concept used at the U3A in Slovakia most often. The study at the U3A consists of two- or three-year-long courses associated with various scientific branches at different faculties. From the beginning of the U3A, improving the quality of life of seniors through educational activities was its basic mission. Recently, the dialogue between generations based on exchange of experience has been the main aim of the U3A (Mühlpachr, 2004, p. 82).

Universities of the Third Age are institutions focused on senior education relating with hobbies, interests in accordance with the concept of lifelong learning following the UNESCO program (Veteška, 2009, p. 168).

Universities of the Third Age include the social, educational, health, economic, psychological, scientific, philosophical function indicating the quality of life of seniors. If students seniors are asked the question about the impact of the study on their lives, besides new knowledge, skills, they mention also new contacts, friends with same interests able to support them in difficult periods of their personal life.

\subsection{Other educational opportunities for seniors}

Universities, as well as academies of the Third Age are the wellknown and at the same time, the most attended institutions focused on senior education. Furthermore, there are programs for seniors carried out by private or non-profit organizations. Following opportunities for seniors are described by Čornaničová (2007, p. 135):

- $\quad$ summer university courses for seniors in the USA, Canada and Germany - specific educational opportunities provided by the universities and their parts,

- university study - chances for senior students to attend universities together with full-time students,

- professionally oriented educational programs for 50+ they started to be run in companies to enhance professional knowledge,

- $\quad$ programs to support social engagement of seniors - seniors are engaged in public life and acquire the knowledge associated with actual issues like ecology or social policy,

- educational activity of public libraries - team and individual educational activities aimed at meeting cultural, educational and creative requirements,

- $\quad$ excursion tours for seniors - organized by institutions in cooperation with universities at home and abroad,

- managed self-education programs for seniors - focused on personal development following personal needs,

- programs aimed at activities of active ageing - tasks connected with health and ageing carried out in cooperation with geriatric medicine,

- memory trainings provided by social facilities,

- consulting services for seniors - in the area of psychology and law provided by consulting firms,

- programs of physical education for seniors - to prevent premature ageing,

- $\quad$ adaptation programs in the retirement homes - individual programs to adapt easily to new environment a style of life,

- educational and rehabilitation programs carried out by social facilities.

Knowledge acquired in the study can help seniors solve problems of everyday life, uncover new values to live by, new philosophy of life and support their social activity (Hrapková, 2004). Place of living and financial demands play an essential role in the selecting from opportunities offered. In general, fees charged by the U3A are not so high but they are mostly located in bigger cities. At the senior age, commuting can be a significant obstacle. On the other hand, opportunities provided by private organizations are not affordable by most seniors. 


\section{ERASMUS+ program}

Erasmus+ program is an example of activity of the European Union in terms of education, professional preparation of young people and sport in the years 2014-2020. All previous programs of the EU including lifelong learning programs (Erasmus, Leonardo da Vinci, Comenius, Grundtvig), the program The Youth in Action and five programs of international cooperation (Erasmus Mundus, Tempus, Alfa, Edulink and program for cooperation with industrialized countries) are joined together. Erasmus+ allow more than four million European citizens to apply for studying abroad, for professional internship or volunteering abroad. It is a program supporting global partnerships between institutions aimed at education, and sport in order to improve cooperation and link education with the needs of job market to reduce lack of skills so common in Europe. Within the program, domestic measures to update education systems are supported.

Education of adults and improving its quality all around Europe is also in the center of attention of ERASMUS+ program. Professionals, employees associated with the adult education have a chance to build strategic partnerships aimed at exchanging the teaching experience. Participants deal with common issues such as accepting the skills gained away from formal education system. Adult education and its availability can help European citizens improve their professional skills through Erasmus+ program. Strategic partnerships provide the opportunity for institutions operating in the education, professional preparation, as well as companies, public bodies, social facilities to cooperate in the process of introducing innovations. Improvement in the quality of education, trainings, internships, work with young generation and modernization as well as social innovation can be considered the result of them. Due to the goals and composition of the strategic partnership, project can be divided into two types:

- $\quad$ strategic partnership supporting innovations focused on developing innovative ideas and/or taking part in activities dealing with spreading and using products and ideas which have already existed or are new. They can be applied in all areas of education, professional preparation.

- strategic partnership supporting changes in proved processes in order to enable organizations to develop and strengthen networks, increase their capacity. Moreover, they are aimed at operating globally, sharing ideas and comparing thoughts. methods and procedures.

At least three institutions from three different countries must participate in the project of strategic partnership. Institutions from so-called partner countries can take part in the project only under specific conditions, their participation must lead to special added value. The number of organizations is not limited, but the budget for managing the project fit for the number of ten participants. Goals, as well as project activities are the most significant factor for selecting the partners.

The world changes very quickly, therefore education system must be updated and new methods of teaching using new opportunities must be implemented. Education, professional preparation and informal learning are key steps in enhancing the competitiveness of Europe. Erasmus+ program can contribute to deal with these challenges significantly.

\subsection{International project My Passion, Happiness - Add to Favorites}

The University of the Third Age at the Technical University in Zvolen is an institution which besides providing education is looking for other opportunities how to use the acquired knowledge in practical situations. Active participation in the projects within the Erasmus+ program make the environment for exchanging the experience in the international cooperation. International activity My Passion, Happiness - Add to Favorites is an example of cooperation of six institutions focusing their activities on seniors in Poland, Portugal, Lithuania, Turkey,
Romania and Slovakia. The main aim of the project was mutual inspiration of participants through creative activities, meetings and arising the interest in individual countries, making friends and fun also at the older age. Development of language and computer skills using innovative methods was one of the large number of activities including in the international meetings within the project. Knowledge of English language, the most often used language in projects, make communication and making friends easier, as well as meeting the project goals. Computer skills and modern technologies shorten the distances, remove the borders and subsequently, provide the chances to create social connections helping seniors stop feeling alone. An effort to join as many participants as it was possible from all partner countries was a positive aspect of the project. International meetings taking 5 days during two years from September 2013 to June 2015 were held in all partner countries. Cultural, sport and social activities were done during meetings in order to introduce the country, customs, traditions, cuisine as well as language of each country.

The project My Passion, Happiness - Add to Favorites showed that intercultural competences must and can be developed at each age. Organizations participating in the project were from countries with different cultures. This was the chance for all participants to familiarize with features typical for each partner country and specially to visit places which the country and its citizens are proud of and which are not mentioned in any tourist guidebooks. Enthusiasm, happiness, and natural curiosity were observed during all activities prepared for participants. In terms of communication, the goal of the project was to encourage seniors to use English language in mutual communication without hesitation. Perfect knowledge of English does not play a significant role in understanding and making friends especially at the older age. Respect for cultural values and cultural identity of individual countries could be seen during the project meeting.

The projects focused on the target group at the older age are of great importance not only for seniors but also for society. Like a prototype of a new person that is aware of their possibilities trying to live the fullest is created.

\section{Conclusion}

Social and economic reality especially in the European Union is connected with the higher intensity of international relationships in all areas of social life. Changes are reflected in education at all levels. Senior education is in the center of attention at all Universities of the Third A. At the present time, their activity started to orient to international cooperation with institutions focused on education of the older generation. In the paper, the possibility of the U3A to participate in the international projects - strategic partnerships funded by the European Union within the Erasmus+ program are presented. Mentioned projects create the environment for exchanging experience and knowledge between institutions resulting in more effective way with this age group. Moreover, the main impact of these projects can be seen in the chance for seniors to familiarize with new nations, cultures and history and this way, they can improve their intercultural competence and can become a part of multicultural society. They can improve the ability to perceive, tolerate and accept diversity and otherness which is around us and become the part of our everyday life. Meeting people at the same age from other countries allow them to make new friends, international contacts which, on one hand, are important in terms of social life and, on the other hand, can help seniors to improve the speaking competence and they can communicate in English better.

\section{Literature:}

1. BALOGOVÁ, B.: Seniori v spektre súčasného sveta. Prešov: Akcent print, 2009. 105 p. ISBN 978-80-89295-19- 7

2. BARTÁK, J.: Profesní vzdělávaní dospělých. Praha: Univerzita Jana Amose Komenského, 2007. 264 p. ISBN 97880-86723-34-1 
3. BARTÁK, J.: Jak vzdělávat dospělé. Praha: Alfa nakladatelství, 2008. 200 p. ISBN 978-80-87197-12-76.

4. BENEŠ, M.: Celoživotní učení a vzdélávaní. In: Nové paradigma $v$ kurikulu vzdélávani dospélých. Praha: Educa Service, 2009. 25-34 p. ISBN 978-80-87306-04-82.

5. BITUŠÍKOVÁ, A.: Kultúrna a sociálna diverzita na Slovensku I. štúdie, dokumenty, materiály. [Cultural and social diversity in Slovakia. Studies, documents, materials.] Bilingválna monografia. Banská Bystrica: Univerzita Mateja Bela, 2007. 114 s. ISBN 978-80-8083-345-9.

6. ČORNANIČOVÁ, R.: Edukácia seniorov. Bratislava: UK, 2007. 163 p. ISBN 978-80-223-2287-4.

7. DARULOVÁ, J. - KOSTIALOVÁ, K.: Multikúlturnost' a multietnicita. Banská Bystrica: ÚVV UMB, 2010. 274 p. ISBN 978-80-557-0018-2.

8. HRAPKOVÁ, N.: Myšlienky k metodike vyučovania seniorov [online]. In: Zborník z metodického seminára. [cit: 2015-03-15] Dostupné na: http://www.uniba.sk/asociaciautv/>

9. JAROŠOVÁ, D.: Péče o seniori. Ostrava: Ostravská Univerzita v Ostravě. Zdravotně sociální fakulta, 2006. 110 p. ISBN 80-7368-110-2.

10. MÜHLPACHR, P.: Gerontopedagogika. Brno: Masarykova univerzita, 2004. 204 p. ISBN 80-210-3345-2

11. PETRUSEK, M.: Sociální a kultúrní antropologie. In: Interkulturní vzdělávání. Praha: Člověk v tísni. Společnost při ČT, o. p. s. 2002.36 s.

12. SWINDELL, R. - THOMSON, J.: An International Perspective on the University of the Third Age. In: Educational Gerontology. Taylor and Francis Online. 2006 Vol. 21, Issue 5, pp. 429-447 doi:10.1080/0360127950210505

13. VACÍNOVÁ, T.: Androdidaktické aspekty vzdělávaní dospelých. In: Kurikulum vo vzdelávaní dospelých. Banská Bystrica: Vydavatel'stvo UMB, 2013. 106-128 p. ISBN 978-80557-0605-4

14. VETEŠKA, J. at al.: Nové paradigma v kurikulu vzdèlávání dospélých. Praha: EDUCA Service, 2009. 344 p. ISBN 978-8087306-04-8

15. VOHRALÍKOVÁ, L., RABUŠIC, L.: Čeští senioři včera, dnes a zítra. Brno: VÚPSV. [online] 2004. [cit. 2019-06-22] Dostupné na internete: http://praha.vupsv.cz/Fulltext/vz_149.pdf 16. RYCHTAŘÍKOVÁ, J.: Úspěšné stárnutí - leitmotiv 21. století. In: Demografie. Praha : Český statistický úřad, 2002, roč. 44, č. 1, pp. 43 - 46, ISSN 0011-8265

17. ZELENICKÁ, E.: Interkultúrne dimenzie a jazykové vzdelávanie dospelých. In: Interkultúrni dimenze ve výuce cizích jazyku. Pardubice: Univerzita Pardubice, 2006. 265-270 p, ISBN 80-7194-893-4.

18. Asociácia univerzít tretieho veku . [online]. [cit: 2018-04-26] Dostupné na: http://asutv.sk/

19. ERASMUS+ - Sprievodca programom [online]. [cit: 201806-16] Dostupné na: https://ec.europa.eu/programmes/erasmusplus/sites/erasmusplus/files/files/resources/2016-erasmus-plusprogramme-guide-v-ii_sk.pdf

Primary Paper Section: A

Secondary Paper Section: AM, AO 